has been listed under each to avoid cross-references. The two other sections are much shorter, and deal with more general publications, articles mainly concerned with the mathematical machinery of quantum mechanics not being included. The lists occupy some 150 pages of small print, and although essentially uncritical, should be of the utmost value to all workers in spectroscopy.

\section{Progress in Modern Physics}

IN his introduction to a set of pamphlets on recent developments in physics ("Exposés de physique théorétique ") published by Hermann et Cie, of Paris ( 6 francs each), Prof. L. de Broglie raises once more the question of how contact can be maintained between workers at different branches of physics. It is now quite impossible for any one person both to read critically all new papers, in any but a most limited field, and to advance the subject himself. Realisation of this is, of course, not new, and has inspired, amongst other publications, the American Physical Society's Reviews of Modern Physics. The present series seems likely, however, to fulfil its purpose better than anything that has gone before. Although definitely for advanced workers, the articles are anything but abstracts, being well written and critical, and containing adequate detail without providing what is really irrelevant to anyone not a specialist in the particular subject dealt with. They also deal with relatively new or very recent work. Of the two at present under notice, Prof. de Broglie's is based on Landau and Peierl's treatment of the uncertainty principle (Z. Phys., vol. 69, p. 56), and is purely theoretical. The other, by Irène Curie and F. Joliot, is an account of the neutron experiments, particularly those done by the workers in Paris; it contains an interesting set of reproductions of Wilson cloud trails, which supplement those recently published by Feather and Dee in the Proceedings of the Royal Society. Each article occupies a little more than twenty pages, and although attractively presented, is certainly cheap.

\section{Cadastral Survey and Land Records}

DURING the Conference of Empire Surveyors held in London last year, there was exhibited at the Science Museum a number of cadastral survey, land registry, and land revenue records. The Royal Geographical Society, at the instance of the Secretary of State for the Colonies, has arranged to house these exhibits, and hopes to make them the nucleus of a permanent reference collection in London. It is expected that the collection will include land laws, regulations, and technical instructions from all parts of the world, and will be representative of progressive advances in cadastral survey and land records in each country. Sir Ernest Dowson and Mr. V. L. O. Sheppard have jointly undertaken the collection, study, and maintenance of the documents.

\section{Oil Fuel for Horticultural Purposes}

THE seventeenth annual report (1931) of the Cheshunt Experimental and Research Station contains a short account of a test with an automatic heating installation using oil fuel. A thermostat in the tomato greenhouse controls the action of a crude oil burner which gives heat to a special hot-water heating boiler. The account is quite short and the experiment incomplete, but the results show that an enhanced yield can be expected from the increased night temperature. Moreover, the fungus disease known as tomato leaf mould was kept in check by the higher temperature.

\section{Announcements}

THE thirty-sixth autumn fungus foray and annual general meeting of the British Mycological Society will be held at Haslemere, Surrey, on Sept. 19-24. Miss G. Lister will deliver the presidential address, entitled "Field Notes on Mycetozoa", on Sept. 21. Several interesting local excursions have been arranged in connexion with the meeting

THe Society of Biological Chemists (India) has made itself responsible for an interesting pamphlet, "Biochemical and Allied Research in India in 1931 ", in which in about forty pages Indian biochemical research in different fields is summarised in a series of brief reviews by some six contributors. The papers cited, of which the majority appear to have been published in 1930 and 1931, number no less than 181. These brief summaries are grouped under various sub-headings-for example, enzymes and fermentation, agricultural chemistry, chemistry of nutrition, etc.-and seem to be very concisely done, so that this little pamphlet should be useful to many biochemical workers outside India.

The Society of Petroleum Geophysicists (America) has issued volume 1 of its Transactions, comprising a series of important papers presented by the Society at the annual convention of the American Association of Petroleum Geologists at San Antonio in March 1931. Most, if not all, of these papers have appeared in the Bulletin of the Association, but now they are available in a convenient, compact form. The titles are: "Application of Seismography to Geological Problems", by E. McDermott; "Belle Isle Torsion-Balance Survey", by D. C. Barton; "Some Results of Magnetometer Surveys in California", by E. D. Lynton; "Magnetic Disturbance caused by Buried Casing", by W. M. Barret ; "Brunton Compass Attachment for Measurement of Horizontal Magnetic Intensity", by J. H. Wilson; "Utilization of Existing Wells in Seismographic Work", by B. McCollum and W. W. La Rue; and an "Analysis of some Torsion-Balance Results in California", by R. H. Miller. The editor is F. H. Lahee, and an introduction has been written by G. H. Westby. The volume can be obtained in England from Messrs. Thomas Murby and Co.

Applications are invited for the following appointments, on or before the dates mentioned :-A male junior assistant (chemistry) at the Experimental Station, Porton, near Salisbury (War Department)-The Chief Superintendent, Chemical Defence Research Department, 14 Grosvenor Gardens, S.W.1 (Sept. 12). A chief workshop instructor in the Mechanical Engineering Department at the Northampton Polytechnic Institute, St. John Street, E.C.1-The Principal (Sept. 15). 